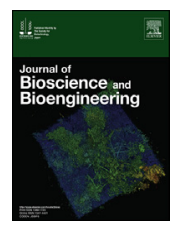

\title{
Simultaneous production of acetic and gluconic acids by a thermotolerant Acetobacter strain during acetous fermentation in a bioreactor
}

\author{
Majid Mounir, ${ }^{1,3, *}$ Rasoul Shafiei, ${ }^{2}$ Raziyeh Zarmehrkhorshid, ${ }^{3}$ Allal Hamouda, ${ }^{1}$ Mustapha Ismaili Alaoui, ${ }^{1}$ \\ and Philippe Thonart ${ }^{3}$
}

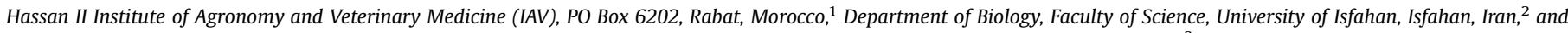
Walloon Centre of Industrial Biology, University of Liege, B40, B-4000 Sart-Tilman, Belgium ${ }^{3}$

Received 10 April 2015; accepted 11 June 2015

Available online 5 August 2015

\begin{abstract}
The activity of bacterial strains significantly influences the quality and the taste of vinegar. Previous studies of acetic acid bacteria have primarily focused on the ability of bacterial strains to produce high amounts of acetic acid. However, few studies have examined the production of gluconic acid during acetous fermentation at high temperatures. The production of vinegar at high temperatures by two strains of acetic acid bacteria isolated from apple and cactus fruits, namely AF01 and CV01, respectively, was evaluated in this study. The simultaneous production of gluconic and acetic acids was also examined in this study. Biochemical and molecular identification based on a 16s rDNA sequence analysis confirmed that these strains can be classified as Acetobacter pasteurianus. To assess the ability of the isolated strains to grow and produce acetic acid and gluconic acid at high temperatures, a semi-continuous fermentation was performed in a 20-L bioreactor. The two strains abundantly grew at a high temperature $\left(41^{\circ} \mathrm{C}\right)$. At the end of the fermentation, the AF01 and CV01 strains yielded acetic acid concentrations of $7.64 \%(w / v)$ and $10.08 \%(w / v)$, respectively. Interestingly, CV01 was able to simultaneously produce acetic and gluconic acids during acetic fermentation, whereas AF01 mainly produced acetic acid. In addition, CV01 was less sensitive to ethanol depletion during semi-continuous fermentation. Finally, the enzymatic study showed that the two strains exhibited high ADH and ALDH enzyme activity at $38^{\circ} \mathrm{C}$ compared with the mesophilic reference strain LMG 1632, which was significantly susceptible to thermal inactivation.

(c) 2015, The Society for Biotechnology, Japan. All rights reserved.
\end{abstract}

[Key words: Acetobacter; Thermoresistant; Bioreactor; Enzyme activity; Acetic acid; Gluconic acid]

Vinegar is considered an acidic product of special importance for the enrichment of our diet. It is the product of the oxidation of substrates that contain ethanol (1). Vinegar is derived from a twostage fermentation process of agriculturally produced raw materials. The two-step process consists of the anaerobic conversion of sugars to ethanol followed by the aerobic oxidation of ethanol to acetic acid (2). This last step is facilitated by acetic acid bacteria (AAB).

The family Acetobacteraceae was first identified by Gillis and De Ley in 1980 (3). Since then, the development and application of new methodologies have significantly changed the taxonomy of AAB (4). At present, the family Acetobacteraceae (Alphaproteobacteria) consists of twelve genera: Acetobacter, Gluconobacter, Acidomonas, Gluconacetobacter, Asaia, Kozakia, Swaminathania, Saccharibacter, Neoasaia, Granulibacter, Tanticharoenia and Ameyamaea (5). Nevertheless, the genus Frateuria belongs to the Xanthomonadaceae family (Gammaproteobacteria) (6).

$A A B$ are found in substrates that contain carbohydrates and/or ethanol, such as fruit juices, wine, cider, beer, and vinegar (7).

$\mathrm{AAB}$ need to be able to oxidize ethanol and tolerate increasing acetic acid concentrations to survive and serve as microbial cell

\footnotetext{
* Corresponding author. Hassan II Institute of Agronomy and Veterinary Medicine (IAV), PO Box 6202, Rabat, Morocco. Tel.: +212 663736 975; fax: +212 537774889 . E-mail address: mounirmajid@gmail.com (M. Mounir).
}

factories for industrial vinegar production in a bioreactor $(8,9)$. Strains should also be temperature-resistant, particularly in tropical and sub-tropical regions. In fact, due to associated economic profits, the production of vinegar by thermotolerant $A A B$ has garnered significant interest (10). Specifically, global warming constitutes a significant challenge to the vinegar industry because large cooling systems are required to maintain the optimal temperatures for vinegar production (8,11). Ndoye et al. (8) isolated and studied thermoresistant $\mathrm{AAB}$ from over-producing crops, such as mangos and cereals, in Senegal and Burkina Faso, respectively (SubSaharan Africa). They isolated an Acetobacter senegalensis strain that was able to grow and oxidize ethanol at high temperatures (8).

The flavour of vinegar reportedly depends on the raw materials used in fermentation (12). Furthermore, selected starter cultures are observed to improve the quality of fermented foods, and aroma is one such quality (13). Therefore, gluconic acid has been proposed as a quality parameter because it contributes to the aromatic profile and viscosity of foods (14). Consequently, AAB strains that simultaneously produce gluconic acid and acetic acid during acetous fermentation are preferable when considering the sensory quality of the final product. In addition, cultivable and phenotypically stable thermotolerant $A A B$ that can be exploited as biocatalysts are increasingly sought after for a number of biotechnological applications (15). 
This study aimed to isolate novel AAB strains whose features make them applicable for industrial use. Thus, we first isolated, identified and characterized novel AAB strains. We then examined the ability of these isolated strains to efficiently ferment ethanol into acetic acid in a lab-scale bioreactor at a high temperature. In addition, the ability of selected strains to simultaneously produce gluconic and acetic acids during acetous fermentation was assessed.

\section{MATERIALS AND METHODS}

Food samples Twenty-two food samples were used in this study. The samples were divided into three categories (traditional vinegars and wines, juices and honeys, and fruits). These samples were collected from different regions of Morocco based on different criteria, such as the climate (hot temperature), availability of local and natural products (non-use of pesticides), and the expertise of local residents. Immediately after collection, the samples were stored at $4{ }^{\circ} \mathrm{C}$.

Culture media and microorganisms GYEA $[20 \mathrm{~g} / \mathrm{L}$ glucose, $5 \mathrm{~g} / \mathrm{L}$ yeast extract, $5 \mathrm{~g} / \mathrm{L}$ peptone of casein, $3 \%(\mathrm{w} / \mathrm{v})$ ethanol and $1 \%(\mathrm{w} / \mathrm{v})$ acetic acid] and GYEA/ $\mathrm{Mg}^{2+}[20 \mathrm{~g} / \mathrm{L}$ glucose, $5 \mathrm{~g} / \mathrm{L}$ yeast extract, $3 \%(\mathrm{w} / \mathrm{v})$ ethanol, $1 \%(\mathrm{w} / \mathrm{v})$ acetic acid and $0.5 \mathrm{~g} / \mathrm{L} \mathrm{MgSO}_{4}$ ] were used as enrichment media (16). Solid culture media (SGYEA and SGYEA $/ \mathrm{Mg}^{2+}$ ) consisted of the same components given above supplemented with $15 \mathrm{~g} / \mathrm{L}$ of agar. GYEA/Mg $\mathrm{Mg}^{2+}$ supplemented with $1 \mathrm{~g} / \mathrm{L} \quad \mathrm{K}_{2} \mathrm{HPO}_{4}$ and $1 \mathrm{~g} / \mathrm{L}$ $\left(\mathrm{NH}_{4}\right)_{2} \mathrm{HPO}_{4}$ was used as the fermentation medium (FM) for acetic fermentation in the bioreactor (17).

The isolated bacteria were compared with other mesophilic and thermotolerant $A A B$. The wild-type strains used in this study were obtained from the Laboratory of Microbiology of Gent (Belgium) (A. senegalensis LMG 23690T, Acetobacter pasteurianus LMG 1632, LMG 1607 and LMG 1701, Acetobacter aceti LMG 1531 and Acetobacter cerevisiae LMG 1625) and from the German Collection of Microorganisms and Cell Cultures (Germany) (A. pasteurianus DSM 2324 and Acetobacter lovaniensis DSM 4491). A. senegalensis, which can grow in liquid culture medium in the presence of ethanol and acetic acid at both mesophilic and thermophilic temperatures, was used as a thermotolerant reference strain $(8,16)$.

Morphological, biochemical and metabolic characterization The morphology of bacteria, including their shape, size, arrangement, gram staining and motility, was characterized using cells grown on GYC at $30^{\circ} \mathrm{C}$ under aerobic conditions $(18,19)$.

Conventional biochemical tests, such as catalase, oxidase, and growth in varying concentrations of ethanol and glucose, were employed according to literature (19). Overoxidation was tested in GYC medium $(20 \mathrm{~g} / \mathrm{L}$ glucose, $5 \mathrm{~g} / \mathrm{L}$ yeast extract, $15 \mathrm{~g} / \mathrm{L}$ agar, and $\left.15 \mathrm{~g} / \mathrm{L} \mathrm{CaCO}_{3}\right)$ containing green bromocresol $(0.022 \mathrm{~g} / \mathrm{L})$.

Carbohydrate assimilation tests were carried out using API 50CH strips (BioMerieux, France). The bacterial cells were first prepared in API 50CHL suspension medium, but that bromocresol purple was replaced with bromocresol green (20). The colour change was examined after 1,2 and 3 days of incubation at $30^{\circ} \mathrm{C}$.

Resistance to high temperatures Growth and acetification were tested at different temperatures: $30^{\circ} \mathrm{C}, 34^{\circ} \mathrm{C}, 35^{\circ} \mathrm{C}, 37^{\circ} \mathrm{C}, 40^{\circ} \mathrm{C}$, and $41^{\circ} \mathrm{C}$.

The thermoresistance basis of thermotolerant isolated $\mathrm{AAB}$ strains and A. senegalensis was compared. Pre-culture $(100 \mathrm{~mL})$ consisting of GYEA/ $\mathrm{Mg}^{2+}$ medium containing $5 \%(\mathrm{v} / \mathrm{v})$ of ethanol and $1 \%(\mathrm{v} / \mathrm{v})$ of acetic acid was prepared in 500 $\mathrm{mL}$ flask for each strain. The flasks were inoculated with fresh colonies grown on plates after $48 \mathrm{~h}$ of incubation at $30^{\circ} \mathrm{C}$ and then incubated simultaneously and separately under agitation at two different temperatures, $30^{\circ} \mathrm{C}$ and $38^{\circ} \mathrm{C}$.

Molecular tests The total genomic DNA of the selected strains was extracted from fresh cells grown on solid GYEA/ $\mathrm{Mg}^{2+}$ medium using the Promega extraction kit (Promega, USA). The cells were resuspended in $600 \mu \mathrm{L}$ of Nuclei Lysis Solution to which $3 \mu \mathrm{L}$ of RNase and $200 \mu \mathrm{L}$ of Protein Precipitation Solution were added. The DNA was precipitated by adding $600 \mu \mathrm{L}$ of isopropanol, and it was then washed in $600 \mu \mathrm{L}$ of $70 \%$ ethanol. The DNA was further resuspended in $100 \mu \mathrm{L}$ of DNA Rehydration Solution ( $10 \mathrm{mM}$ Tris and $1 \mathrm{mM}$ EDTA) and preserved at $4^{\circ} \mathrm{C}$. The quantity of extracted DNA was estimated by agarose gel electrophoresis.

The 16s rRNA gene was amplified using PCR and the following universal primers: 16SP0 5'-GAAGAGTTTGATCCTGGCTCAG-3' for the coding segment and 16SP6 5'-CTACGGCTACCTTGTTACGA-3' for the non-coding segment $(8,21)$. The PCR reaction was performed in 200- $\mu \mathrm{L}$ Eppendorf tube containing $25 \mu \mathrm{L}$ of Ready Mix (Promega), $2.5 \mu \mathrm{L}$ of $16 \mathrm{SPO}$ primer, $2.5 \mu \mathrm{L}$ of $16 \mathrm{SP} 6$ primer, $2 \mu \mathrm{L}$ of DNA template and $18 \mu \mathrm{L}$ of sterile Milli-Q water.

The conditions of the PCR reaction, which was carried out in a thermocycler (Eppendorf, France) were as follows: an initial denaturation cycle at $95^{\circ} \mathrm{C}$ for $5 \mathrm{~min}$, 25 denaturation cycles at $95^{\circ} \mathrm{C}$ for $30 \mathrm{~s}$, primer annealing at $55^{\circ} \mathrm{C}$ for $30 \mathrm{~s}$, primer elongation at $72^{\circ} \mathrm{C}$ for $2 \mathrm{~min}$, and a final elongation cycle at $72^{\circ} \mathrm{C}$ for $10 \mathrm{~min}$. The PCR products were then electrophoresed at $100 \mathrm{~V}$ for $20 \mathrm{~min}$ in a $1 \%$ agarose gel in $50 \times$ phosphate TAE buffer containing $1 \mu \mathrm{g} / \mathrm{mL}$ ethidium bromide.

The PCR reaction products were purified using a PCR Preps Wizard kit (Promega) and quantified on an agarose gel.
The purified PCR product was sequenced according to the Sanger method using a Big Dye Kit and a 3730 DNA analyser (Applied Biosystems) (8). The following primers were used for sequencing: F1 (CTGGCTCAGGAYGAACG), F2 (GAGGCAGCAGTRGGGAAT), F3 (ACACCARTGGCGAAGGC), and F4 (GCACAAGCGGYGGAGCAT) for the coding DNA segment and R1 (CTGCTGGCACGTAGTTAG), R2 (AATCCTGTTYGCTMCCCA), R3 (CCAACATCTCACGACACG) and R4 (TGTGTAGCCCWGGTCRTAAG) for the non-coding DNA segment.

The products of the sequencing reaction were assembled using the CodonCode Aligner program. The sequence was then analysed using the BLAST algorithm from GenBank of National Center for Biotechnology Information (NCBI) and was compared with others available in the GenBank/EMBL/DDBJ database.

Analytical methods The compositions of liquid culture media and fermentation broth were analysed by HPLC (Agilent 1110 series; Agilent Technologies, CA, USA) using the method described by Shafiei et al. (16,22).

The total amount of produced biomass was determined by measuring the absorbance of the culture on a spectrophotometer at $540 \mathrm{~nm}$ (O.D. measured by spectrophotometer). For all samples, the cultivated broth was diluted to an O.D. of less than 0.8 .

The total acidity $(\% \mathrm{w} / \mathrm{v})$ of the samples was measured via titration with $0.5 \mathrm{~N}$ $\mathrm{NaOH}$ using phenolphthalein as a $\mathrm{pH}$ indicator.

Growth and fermentation kinetics of the selected strains Two strains were selected, studied and compared with other mesophilic and thermoresistant strains. The growth kinetics of these isolates was monitored in flasks and bioreactor and compared with those of $A$. senegalensis.

A 20-L stirred tank bioreactor (Biolafitte, France) was used for the fermentations. The bioreactor was divided into a headspace volume and a working volume of $15 \mathrm{~L}$. A computer connected to the fermenter allowed for the control of fermentation parameters: temperature, agitation, partial pressure of dissolved oxygen and $\mathrm{pH}$. The reactor was aerated using a continuous flow of filtered sterile air at a rate of 1 VVM. The stirring rate was controlled to provide a minimum dissolved oxygen concentration $60 \%$. The fermentations were conducted at $38^{\circ} \mathrm{C}$.

The pre-culture was prepared in a 5-L embossed flask containing $1 \mathrm{~L}$ of GYEA/ $\mathrm{Mg}^{2+}$ culture medium. The flask was inoculated with fresh cells that were grown for $48 \mathrm{~h}$ on plates. The flask was then incubated on a shaker $(120 \mathrm{rpm})$ at $38^{\circ} \mathrm{C}$.

After 24-36 h of incubation (O.D. between 0.2 and 0.4 ), the pre-culture was used to inoculate the bioreactor. The bioreactor was filled with fermentation medium (FM) with initial ethanol and acetic acid concentrations of $5 \%(\mathrm{v} / \mathrm{v})$ and $1 \%(\mathrm{v} / \mathrm{v})$, respectively.

The fermentations were semi-continuous: when the concentration of the substrate (ethanol) approached $0,3 \mathrm{~L}$ of the cultivation medium was replaced by the same volume of fresh FM.

Enzymatic study The activities of the enzymes responsible for the production of acid, namely alcohol dehydrogenase (ADH) and aldehyde dehydrogenase $(\mathrm{ALDH})$, were studied at the tested temperature $\left(38^{\circ} \mathrm{C}\right)$. The cells were centrifuged, washed and used to determine the enzymatic activity according to the procedure used by Wood et al. (23) and Blandino et al. (24) and adjusted by Ndoye et al. (8), which utilizes ferricyanide as an electron acceptor.

A protease inhibitor cocktail (P8849; Sigma Aldrich, Germany) was added to the washed cells before lysis. The cell suspension was lysed by sonication in a Bandelin Sonifier (Germany) (15 bursts of $30 \mathrm{~s}$ with intermittent cooling) (25). The cells were maintained on ice during sonication.

The specific enzyme activity is expressed as units per milligram of proteins, and the protein content was determined through a Bradford assay using bovine serum albumin (BSA) as a standard (8,23-27).

\section{RESULTS AND DISCUSSION}

Isolation of adapted thermotolerant $\mathbf{A A B}$ This study aimed to isolate thermotolerant AAB strains from Moroccan products. The screening of liquid samples (Table 1 ) showed that all but the date vinegar and traditional apple vinegar strains abundantly grew at either $35^{\circ} \mathrm{C}$ or $41^{\circ} \mathrm{C}$ in different culture media. The thermoresistance of all of the strains inversely correlated with the concentrations of acetic acid and ethanol. A similar relationship between thermoresistance and ethanol concentration has been reported by Maal et al. (28). Notably, the AF01 strain, which was isolated from apple fruits, grew better at $41^{\circ} \mathrm{C}$ than at $35^{\circ} \mathrm{C}$. Moreover, the traditional apple vinegar isolate weakly grew at $41^{\circ} \mathrm{C}$ compared with the other strains. However, this strain was more resistant to acetate and ethanol at $35^{\circ} \mathrm{C}$ than the other strains.

The comparison of the five thermotolerant strains revealed that AF01 and CV01, which were isolated from apple and cactus fruits, respectively, were the most thermoresistant strains (good growth at $35^{\circ} \mathrm{C}$ and $41^{\circ} \mathrm{C}$ ). Therefore, AF01 and CV01 were selected for subsequent investigations. 
TABLE 1. Thermoresistance test of the selected strains on solid GYEA medium.

\begin{tabular}{|c|c|c|c|c|c|c|c|c|c|c|c|c|c|c|}
\hline \multirow[t]{3}{*}{ Source of isolation ${ }^{a}$} & \multicolumn{14}{|c|}{ Culture conditions ${ }^{\mathrm{b}}$} \\
\hline & \multicolumn{2}{|c|}{$0 \mathrm{~A}, 3 \mathrm{E}$} & \multicolumn{2}{|c|}{$0.2 \mathrm{~A}, 3 \mathrm{E}$} & \multicolumn{2}{|c|}{$1 \mathrm{~A}, 3 \mathrm{E}$} & \multicolumn{2}{|c|}{$1 \mathrm{~A}, 5 \mathrm{E}$} & \multicolumn{2}{|c|}{$2 \mathrm{~A}, 5 \mathrm{E}$} & \multicolumn{2}{|c|}{$3 \mathrm{~A}, 5 \mathrm{E}$} & \multicolumn{2}{|c|}{$4 \mathrm{~A}, 5 \mathrm{E}$} \\
\hline & $35^{\circ} \mathrm{C}$ & $41^{\circ} \mathrm{C}$ & $35^{\circ} \mathrm{C}$ & $41^{\circ} \mathrm{C}$ & $35^{\circ} \mathrm{C}$ & $41^{\circ} \mathrm{C}$ & $35^{\circ} \mathrm{C}$ & $41^{\circ} \mathrm{C}$ & $35^{\circ} \mathrm{C}$ & $41^{\circ} \mathrm{C}$ & $35^{\circ} \mathrm{C}$ & $41^{\circ} \mathrm{C}$ & $35^{\circ} \mathrm{C}$ & $41^{\circ} \mathrm{C}$ \\
\hline DV & $++^{c}$ & + & ++ & + & + & + & + & \pm & \pm & - & \pm & - & - & - \\
\hline RAV & ++ & +++ & ++ & + & +++ & +++ & \pm & \pm & ++ & + & + & \pm & \pm & - \\
\hline TAV & ++ & + & +++ & - & +++ & - & +++ & - & +++ & - & +++ & - & ++ & - \\
\hline $\mathrm{CV}$ & + & + & ++ & ++ & +++ & ++ & ++ & ++ & ++ & ++ & ++ & + & + & \pm \\
\hline AJ & + & ++ & + & + & ++ & + & ++ & ++ & + & \pm & \pm & + & \pm & - \\
\hline $\mathrm{AF}$ & ++ & ++ & ++ & +++ & ++ & ++ & ++ & +++ & ++ & ++ & + & + & \pm & \pm \\
\hline
\end{tabular}

a Origin of selected strains: DV, date vinegar; RAV, rosemary apple vinegar; TAV, traditional apple vinegar; CV, cactus vinegar; AJ, apple juice; AF, apple fruit.

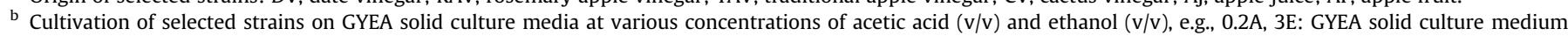
containing $0.2 \%(\mathrm{v} / \mathrm{v})$ acetic acid and $3 \%(\mathrm{v} / \mathrm{v})$ ethanol.

${ }^{c}$ Level of growth: +++ , very good growth; ++, good growth; +, weak growth; \pm , very weak growth; - , no growth.

Biochemical and molecular identification Conventional biochemical and morphological tests performed following the guidelines of Bergey's Manual of Systematic Bacteriology (19) revealed that all the isolated bacteria were gram-negative, catalase-positive and oxidase-negative. Morphologically, they appeared as single or paired cocci on GYC agar.

The analysis of liquid fermented media revealed that all strains were able to convert ethanol to acetic acid. They can also convert acetate to $\mathrm{CO}_{2}$ and $\mathrm{H}_{2} \mathrm{O}$ after a several days on bromocresolcontaining GYC medium. Other biochemical tests, such as those for the growth in the presence of high glucose concentrations, utilization of ammonium, assimilation of different carbohydrates and utilization of ethanol, revealed that all strains belonged to the Acetobacter genus.

Molecular identification was performed according a phylogenetic analysis based on the sequencing of the gene coding for $16 \mathrm{~S}$ ribosomal RNA, the component of the 30 S small ribosomal subunit (29).

The studied species were identified based on reference strains by a digested PCR-amplified fragment analysis of the partial sequence of $16 \mathrm{~S}$ rDNA. The alignments sequences were obtained from the GenBank databases (30).

AF01 and CV01, which were isolated from apple and cactus fruits, respectively, are closely related to A. pasteurianus [99\% and $98 \%$ homology, respectively (query cover)]. However, TAV01, which was isolated from traditional apple vinegar, was assigned to Gluconacetobacter xylinus (more than $98 \%$ homology).

Phenotypic differentiation of selected thermoresistant strains The thermoresistance features of the two studied strains, AF01 and CV01, required additional phenotypic differentiation. The assimilation of carbon sources by these strains was compared to that of wild-type strains using API 50CH strips (8).

The ability to assimilate carbon sources differed between the CV01 and AF01 strains and the wild-type A. pasteurianus LMG 1632 and $A$. senegalensis LMG 23690T strains. CV01 was the only strain that could assimilate L-xylose. AF01 was the only strain among the studied $A$. pasteurianus species that could assimilate both glycerol and D-mannose. In addition, the types of metabolized carbohydrates differed between CV01 and AF01. Therefore, the biochemical profiles of the two studied strains differed. These findings permit the genotypic and phenotypic differentiation of the two isolates.

Growth kinetics and fermentation of the isolated strains In addition to the thermotolerance properties, this study aimed to identify novel features in selected strains intended for the production of fruit vinegar. To this end, the ability of selected thermotolerant strains to produce gluconic acid during acetous fermentation was assessed.

The first part of this study was performed on plates containing SGYEA medium, and the cells were incubated at four different temperatures: $30^{\circ} \mathrm{C}, 34^{\circ} \mathrm{C}, 37^{\circ} \mathrm{C}$ and $40^{\circ} \mathrm{C}$. Bromocresol green $(0.022 \mathrm{~g} / \mathrm{L})$ was added to the medium to reveal acidification and over-oxidation phenomena. The growth and bioconversion capacities of the two studied strains, AF01 and CV01, were compared with those of the thermoresistant reference strain $A$. senegalensis and other wild-type strains belonging to A. pasteurianus: LMG 1632, LMG 1607, LMG 1701, DSM 2324 and DSM 4491.

All of the strains grew well at $30^{\circ} \mathrm{C}$. At temperatures greater than $34^{\circ} \mathrm{C}$, almost all of the wild-type strains exhibited significant decreases in growth. AF01, CV01 and A. senegalensis grew well at $37^{\circ} \mathrm{C}$, whereas the reference strains showed weak or no growth. Only AF01, CV01 and $A$. senegalensis continued to grow and produce acetic acid at $40^{\circ} \mathrm{C}$. Of these strains, AF01 grew best at $40^{\circ} \mathrm{C}$ (Table 2).

In addition, the growth kinetics and fermentation behaviour of AF01 and $A$. senegalensis on liquid medium were compared. Fig. 1 shows that AF01 produced more biomass than A. senegalensis at both $30^{\circ} \mathrm{C}$ and $38^{\circ} \mathrm{C}$. The average values of the final turbidity measured at $540 \mathrm{~nm}$ were 1.29 and 1.42 for the AF01 strain at $30^{\circ} \mathrm{C}$ and $38^{\circ} \mathrm{C}$, respectively; these values were 0.94 and 0.76 for A. senegalensis at $30^{\circ} \mathrm{C}$ and $38^{\circ} \mathrm{C}$, respectively.

Moreover, AF01 produced more biomass during fermentation at $38^{\circ} \mathrm{C}$ than at $30^{\circ} \mathrm{C}$ (Fig. 1). This finding suggests that AF01 is thermotolerant.

Furthermore, AF01 produced more acetic acid than A. senegalensis. At $30^{\circ} \mathrm{C}, \mathrm{AF} 01$ and $A$. senegalensis produced an average of $43.67 \mathrm{~g} / \mathrm{L}$ and $43.56 \mathrm{~g} / \mathrm{L}$ acetic acid, respectively, whereas these levels were $45.1 \mathrm{~g} / \mathrm{L}$ and $31.16 \mathrm{~g} / \mathrm{L}$, respectively, at $38^{\circ} \mathrm{C}$. Notably, AF01 produced more acetic acid at $38^{\circ} \mathrm{C}$ than at $30^{\circ} \mathrm{C}$.

Furthermore, AF01 strain was able to oxidize all available ethanol at both temperatures, $30^{\circ} \mathrm{C}$ and $38^{\circ} \mathrm{C}$. This strain also oxidized almost all available ethanol after only $26 \mathrm{~h}$ at $38^{\circ} \mathrm{C}$, whereas the same result was obtained after $48 \mathrm{~h}$ at $30^{\circ} \mathrm{C}$. Therefore, this bacterium is thermotolerant.

TABLE 2. Comparison of growth, acidification and overoxidation capacities between selected strains (AF01 and CV01) and other AAB.

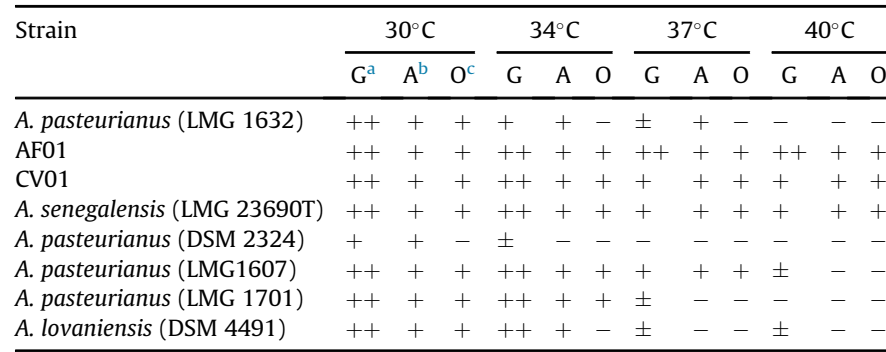

Growth: -, no growth; + , weak growth; +, good growth; ++, very good growth

Acidification: + , positive test; - , negative test.

Over-oxidation: + , positive test; - , negative test. 

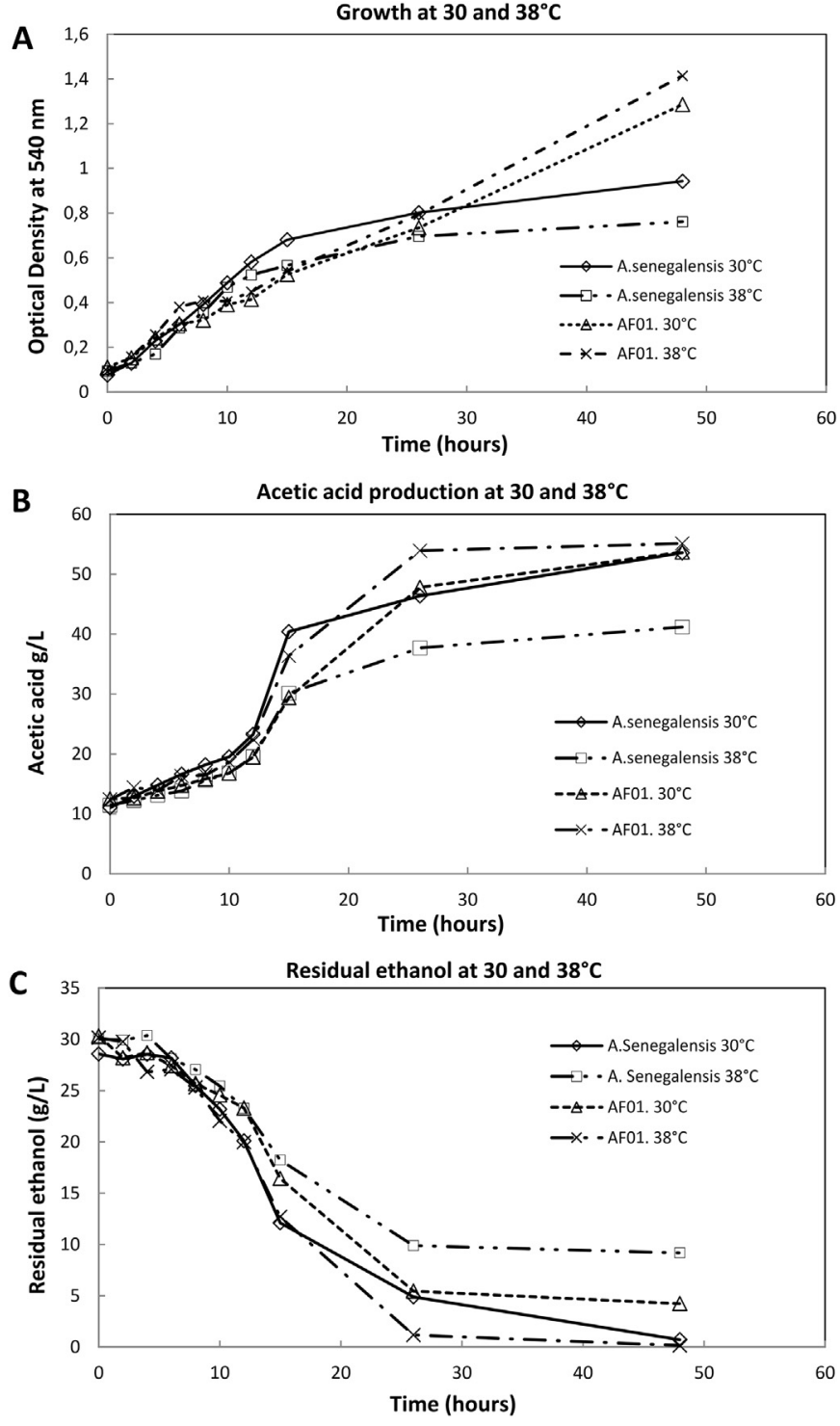

FIG. 1. Growth (A), acetic acid production (B) and oxidation of ethanol (C) by AF01 (open triangles and cross symbols) and $A$. senegalensis (open diamonds and open squares) at $30^{\circ} \mathrm{C}$ and $38^{\circ} \mathrm{C}$ on GYEA liquid medium containing initial acetic acid and ethanol concentrations of $1 \%(\mathrm{v} / \mathrm{v})$ and $5 \%(\mathrm{v} / \mathrm{v})$, respectively, as well as $0.5 \mathrm{~g} / \mathrm{L}$ of $\mathrm{MgSO}_{4}$. The presented results are the means of two independent replications.

Acetic acid fermentation by AF01 and CV01 strains in a bioreactor Semi-continuous fermentation was performed in a 20-L bioreactor for both selected strains, AF01 and CV01.

AF01 was tested first. This strain was thermotolerant on solid and liquid media. Fig. 2A shows that AF01 exhibited a 23-h lag phase. Subsequently, the cells grew exponentially, and their growth slightly slowed after the addition of the second batch, ultimately reaching an OD of 1.54 before the third batch was added. In parallel, acetic acid accumulated in the culture during this phase at an average rate of $0.83 \mathrm{~g} / \mathrm{L} / \mathrm{h}$. Immediately after the addition of the third batch, the cell growth and acetification rates considerably decreased. The final acetic acid concentration reached $7.64 \%$ at the end of the fermentation.

The CV01 strain was also tested in a parallel bioreactor. As shown in Fig. 2B, the lag phase of this bacterium was significantly shorter $(5 \mathrm{~h})$ than that of AF01. Furthermore, the production of acetic acid began later in the mid-log phase. The biomass and acidification rates slightly decreased and then recovered after the
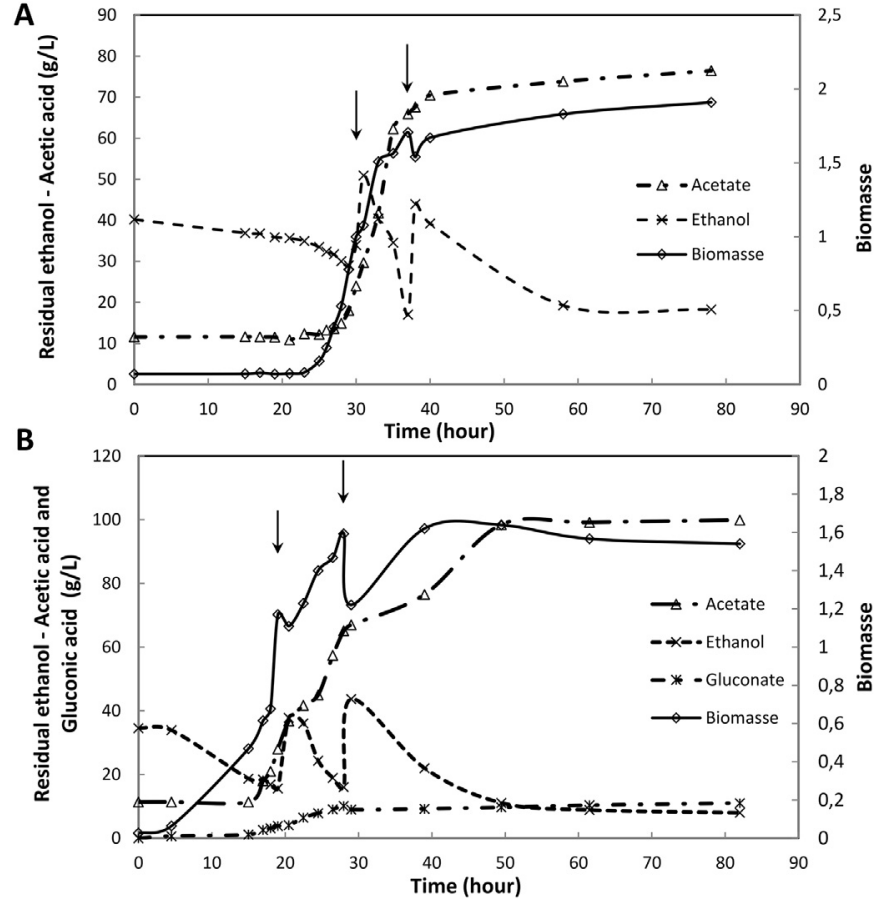

FIG. 2. Acetic acid, ethanol, gluconic acid and biomass production during the semicontinuous fermentation of AF01 (A) and CV01 (B) in a 20-L bioreactor at $38^{\circ} \mathrm{C}$. The FM used for cultivation contained initial ethanol and acetic acid concentrations of $5 \%$ $(\mathrm{v} / \mathrm{v})$ and $1 \%(\mathrm{v} / \mathrm{v})$, respectively. Arrows indicate the points at which a new fermentation cycle was started via the addition of fresh FM.

addition of each batch due to the dilution that results from the addition of fresh medium. In total, $10 \%(\mathrm{w} / \mathrm{v})$ of acetic acid was produced at an average rate of $1.08 \mathrm{~g} / \mathrm{L} / \mathrm{h}$. Furthermore, the residual amount of ethanol after fermentation with this strain is lower than that obtained after fermentation with AF01 (7.97 g/L with CV01 compared with $19.02 \mathrm{~g} / \mathrm{L}$ with AF01).

AF01 was sensitive to increased acetic acid concentrations, likely because acetic acid affects cell growth (31). This result corroborated the evolution of the biomass.

The ability of the isolated strains to produce gluconic acid during acetous fermentation was also investigated. CV01 was the only strain that transformed some of the glucose present in the fermentation medium to gluconic acid while oxidizing ethanol (Fig. 2B). The final amount of gluconic acid produced at the end of cultivation in the bioreactor was $11.03 \mathrm{~g} / \mathrm{L}$. This production represents an additional advantage for this strain because gluconic acid and its derivatives are widely applicable in the food and pharmaceutical industries (32). Specifically, gluconic acid is considered a sensory quality indicator in the production of vinegar.

The microbial production of Na-gluconate in batch processes at high temperatures $\left(38-40^{\circ} \mathrm{C}\right)$ was also investigated by Zarmehrkhorshid et al. (33).

Gluconic acid increases the biotechnological value of produced vinegar. Gluconic acid has been proposed as quality parameter of traditional balsamic vinegar because it contributes to the aromatic profile and viscosity of the vinegar $(34,35)$. Acetic acid fermentation contributes to the vinegar aroma profile by converting some compounds present in fruit juices to aromatic compounds, such as gluconic acid and acetoin, which are obtained from glucose and DLlactate, respectively (36).

Some AAB have been reported to produce gluconic acid from glucose. This reaction is catalysed by glucose dehydrogenase (GDH) $(32,33)$. However, few studies reported the simultaneous ability of 

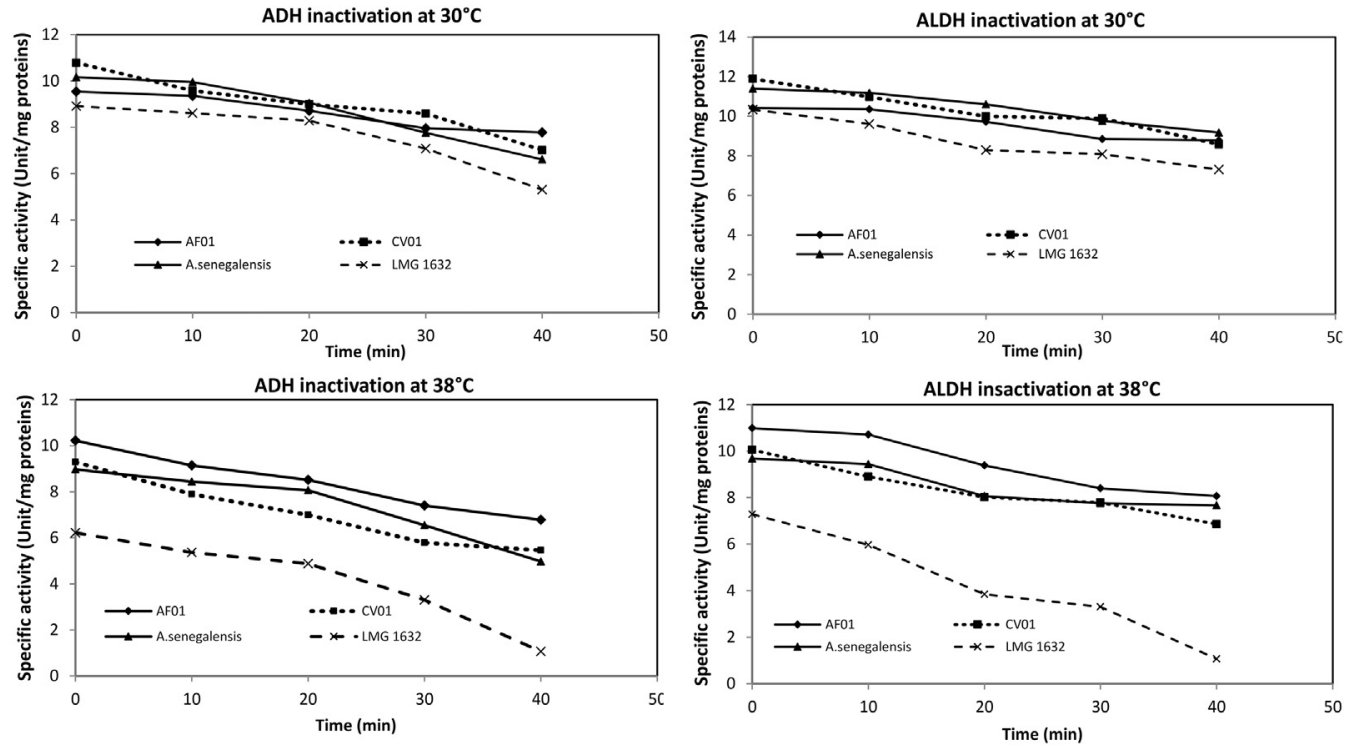

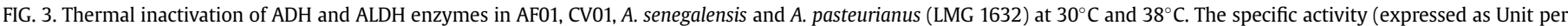

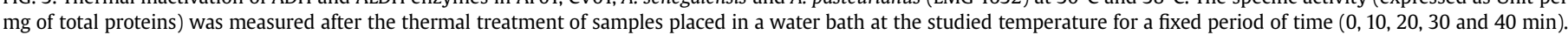

$\mathrm{AAB}$ strains to produce acetic and gluconic acids in the same fermentation cycle $(25,37)$.

With regard to the acclimation and heritable adaptation of $A A B$ strains in growth culture conditions, Azuma et al. (38) reported that the genetic instability and hyper-mutability of $A$. pasteurianus strains are responsible for the gradual acquisition of resistance against high temperatures. Furthermore, the cultivability and phenotypic stability of $A A B$ species were studied by Gullo et al. (15). The oxidation of ethanol to acetic acid by A. pasteurianus AB0220 remained stable during long-time preservation (LTP), which confirmed the suitability of the LTP technique for AAB belonging to A. pasteurianus.

Several fermentation cycles of AF01 were monitored in the bioreactor. AF01 was very sensitive to changes in the fermentation conditions of the cultivation medium during later cycles, despite its thermoresistance. This behaviour was considered a negative characteristic of this strain regarding its use in industrial vinegar production.

Enzymatic study The activity of enzymes responsible for the acetic fermentation process was analysed in the selected thermoresistant strains, AF01 and CV01, to confirm the thermoresistance of the enzymes. The activities of ADH and ALDH in AF01 and CV01 were compared to those of the thermoresistant reference strain $A$. senegalensis and the mesophilic strain $A$. pasteurianus (LMG1632). The enzymes were incubated for 10, 20, 30 and $40 \mathrm{~min}$ at $30^{\circ} \mathrm{C}, 34^{\circ} \mathrm{C}$ and $38^{\circ} \mathrm{C}$, and the residual enzyme activity was then measured.

Fig. 3 shows that the three strains, CV01, AF01 and A. senegalensis, exhibited high ADH and ALDH enzyme activity at $30^{\circ} \mathrm{C}$ and $38^{\circ} \mathrm{C}$ compared with the mesophilic reference strain LMG 1632. However, ADH and ALDH were more resistant to deactivation at $38^{\circ} \mathrm{C}$ in the mesophilic reference strain than in the other strains. In addition, the thermal inactivation rates of ADH and ALDH were higher at $38^{\circ} \mathrm{C}$ than at $30^{\circ} \mathrm{C}$ for all of the strains, and $\mathrm{ADH}$ was more thermosensitive than ALDH. Thus, ADH was less thermostable than ALDH. These results agree with the results obtained by Ndoye et al. (8) and Saecki et al. (10).

Interestingly, the initial activities of both ADH and ALDH in AF01 were higher at high temperatures (10.19 and 10.98 for ADH and ALDH, respectively, at $38^{\circ} \mathrm{C}$ vs. 9.54 and 10.41 for ADH and ALDH, respectively, at $30^{\circ} \mathrm{C}$ ). These results agree with the thermotolerant characteristic of this bacterium observed.

A comparative study of acetic acid productivity of wild-type AAB used for ethanol oxidation was reported by Gullo et al. (39). Overall, mesophilic strains exhibited a significant acetic acid yield with respect to thermotolerant species (39). However, thermo-adapted strains (which stably perform efficient acetous fermentation at high temperatures) were obtained after a number attempts to isolate thermotolerant mutants $(39,40)$. Thus, some authors have elucidated the role of a number of genes involved in AAB thermotolerance $(39,41)$.

Two practical conclusions can be deduced from this study: (i) Because AF01 and CV01 could grow and produce acetic acid at high temperatures under semi-continuous conditions, they may be useful as industrial thermotolerant strains, especially in subtropical regions. Therefore, future studies should test these strains in a pilot plant bioreactor. In addition, their ability to costeffectively produce starter should be studied. (ii) Unlike most AAB strains, CV01 was able to simultaneously produce gluconic acid and acetic acid during acetous fermentation. This feature is very important because it is rarely observed in $A A B$ and helps improve the taste of vinegar.

\section{ACINOWLEDGMENTS}

This work was supported by the BTC (Belgian Development Agency) (grant number 12MOR/0113). The authors would like to thank the BTC for its financial support via the scholarship granted to M. Mounir to conduct this research.

\section{References}

1. Solieri, L. and Giudici, P.: Vinegars of the world, pp. 1-16, in: Solieri, L. and Giudici, P. (Eds.), Vinegars of the world. Springer, Milan, Italy (2009).

2. Saha, P. and Banerjee, S.: Optimization of process parameters for vinegar production using banana fermentation, Int. J. Res. Eng. Technol., 2, 501-514 (2013)

3. Gillis, M. and De Ley, J.: Intra- and intergeneric similarities of the ribosomal ribonucleic acid cistrons of Acetobacter and Gluconobacter, Int. J. Syst. Evol. Microbiol., 30, 7-27 (1980).

4. Cleenwerck, I. and De Vos, P.: Taxonomy of acetic acid bacteria and molecular techniques suitable for their identification at the species level, abstract no. S2KN-01Abstracts: Third International Conference on Acetic Acid Bacteria, 
Vinegar and other products, April 17-20, 2012, Cordoba, Spain. Pagepress, Italy (2012).

5. Sengun, I. Y. and Karabiyikli, S.: Importance of acetic acid bacteria in food industry, Food Control, 22, 647-656 (2011).

6. Yamada, Y. and Yukphan, P.: Genera and species in acetic acid bacteria, Int. J. Food Microbiol., 125, 15-24 (2008).

7. Guillamónmón, J. M. and Mas, A.: Acetic acid bacteria, pp. 227-255, in: Carrascosa, A. F. and MuñozRamón González, R. (Eds.), Molecular wine microbiology. Academic Press, San Diego ( (2011).

8. Ndoye, B., Lebecque, S., Dubois-Dauphin, R., Tounkara, L., Guiro, A. T., Kere, C., Diawara, B., and Thonart, P.: Thermoresistant properties of acetic acids bacteria isolated from tropical products of Sub-Saharan Africa and destined to industrial vinegar, Enzyme Microb. Technol., 39, 916-923 (2006).

9. Garcia Garica, I. and Gullo, M.: Acetic acid bacteria: features and impact in bioapplications, Acetic Acid Bact., 2, 1 (2013).

10. Saeki, A., Theeragol, G., Matsushita, K., Toyama, H., Lotong, N., and Adachi, 0.: Development of thermotolerant acetic acid bacteria useful for vinegar fermentation at higher temperatures, Biosci. Biotechnol. Biochem., 61, 138-145 (1997).

11. Amornrut, M. and Wasu, P. A.: Isolation of thermotolerant acetic acid bacteria from fruits for vinegar production, Res. J. Microbiol., 3, 209-212 (2008).

12. Natera Marín, R., Castro Mejías, R., De Valme García Moreno, M., García Rowe, F., and García Barroso, C.: Headspace solid-phase microextraction analysis of aroma compounds in vinegar: validation study, J. Chromatogr. A, 967, 261-267 (2002).

13. Gullo, M., De Vero, L., and Giudici, P.: Succession of selected strains of Acetobacter pasteurianus and other acetic acid bacteria in traditional balsamic vinegar, Appl. Environ. Microbiol., 75, 2585-2589 (2009).

14. Falcone, P., Chillo, S., Giudici, P., and Del Nobile, M.: Measuring rheological properties for applications in quality assessment of traditional balsamic vinegar: description and preliminary evaluation of a model, J. Food Eng., 80, 234-240 (2007)

15. Gullo, M., Mamlouk, D., De Vero, L., and Giudici, P.: Acetobacter pasteurianus strain AB0220: cultivability and phenotypic stability over 9 years of preservation, Curr. Microbiol., 64, 576-580 (2012).

16. Shafiei, R., Delvigne, F., Babanezhad, M., and Thonart, P.: Evaluation of viability and growth of Acetobacter senegalensis under different stress conditions, Int. J. Food Microbiol., 163, 204-213 (2013).

17. Ndoye, B., Lebecque, S., Destain, J., Guiro, A. T., and Thonart, P.: A new pilot plant scale acetifier designed for vinegar production in Sub-Saharan Africa, Process Biochem., 42, 1561-1565 (2007).

18. Cleenwerck, I., Vandemeulebroecke, K., Janssens, D., and Swings, J.: Re-examination of the genus Acetobacter, with descriptions of Acetobacter cerevisiae sp. nov. and Acetobacter malorum sp. nov, Int. J. Syst. Evol. Microbiol., 52 1551-1558 (2002).

19. De Ley, J., Gillis, M., Swings, J., Krieg, N. R. and Holt, J. G. (Eds.), Bergy's manual of systematics bacteriology, vol. 1. Williams \& Wilkins, Boltimore, London ( (1984).

20. Ndoye, B., Cleenwerck, I., Engelbeen, K., Dubois-Dauphin, R., Guiro, A. T., Van Trappen, S., Willems, A., and Thonart, P.: Acetobacter senegalensis sp. nov., a thermotolerant acetic acid bacterium isolated in Senegal (sub-Saharan Africa) from mango fruit (Mangifera indica L.), Int. J. Syst. Evol. Microbiol., 57, 1576-1581 (2007).

21. Ventura, M., Casas, I., Morelli, L., and Callegari, M. L.: Rapid amplified ribosomal DNA restriction analysis (ARDRA) of Lactobacillus spp. isolated from fecal and vaginal samples, Syst. Appl. Microbiol., 23, 504-509 (2000).

22. Shafiei, R., Zarmehrkhorshid, R., Bentaib, A., Babanezhad, M., Leprince, P., Delvigne, F., and Thonart, P.: The role of protein modifications in senescence of freeze-dried Acetobacter senegalensis during storage, Microb. Cell Fact., 13, 26 (2014).
23. Wood, W. A., Fetting, R. A., and Hertlein, B. C.: Gluconic dehydrogenase from Pseudomonas fluorescens, pp. 287-291, in: Colowick, S. P. and Kaplan, N. O. (Eds.), Methods in enzymology, vol. V. Academic Press, New York ( (1962).

24. Blandino, A., Caro, I., and Cantero, D.: Effect of culture conditions on the aldehyde dehydrogenase activity of Acetobacter aceti cytoplasmatics extracts, Biotechnol. Lett., 18, 63-68 (1996).

25. Attwood, M. M., Van Dijken, J. P., and Pronk, J. T.: Glucose metabolism and gluconic acid production by Acetobacter diazotrophicus, J. Ferment. Bioeng., 72, 101-105 (1991).

26. Lowry, O. H., Rosebrough, N. J., Farr, A. L., and Randall, J. R.: Protein measurement with the folin phenol reagent, J. Biol. Chem., 193, 265-275 (1951).

27. Shinagawa, E., Toyama, H., Matsushita, K., Tuitemwong, P., Theeragool, G., and Adachi, 0.: A novel type of formaldehyde-oxidizing enzyme from the membrane of Acetobacter sp. SKU 14, Biosci. Biotechnol. Biochem., 70, 850-857 (2006).

28. Maal, K. B., Shafiei, R., and Kabiri, N.: Production of apricot vinegar using an isolated Acetobacter strain from Iranian Apricot, Int. J. Biol. Life Sci., 6, 230-233 (2010).

29. Trcek, J. and Teuber, M.: Genetic restriction analysis of the 16S-23S rDNA internal transcribed spacer regions of the acetic acid bacteria, FEMS Microbiol. Lett., 208, 69-75 (2002).

30. Poblet, M., Rozes, N., Guillamon, J. M., and Mas, A.: Identification of acetic acid bacteria by restriction fragment length polymorphism analysis of a PCRamplified fragment of the gene coding for $16 \mathrm{~S}$ rRNA, Lett. Appl. Microbiol., 31, 63-67 (2000)

31. De Ory, I., Romero, E. L., and Cantero, D.: Optimum starting-up protocol of a pilot plant scale acetifier for vinegar production, J. Food Eng., 52, 31-37 (2002).

32. Ramachandran, S. and Fontanille, P.: Gluconic acid: properties, applications and microbial production, Food Technol. Biotechnol., 44, 185-195 (2006).

33. Zarmehrkhorshid, R., Shafiei, R., and Thonart, P.: Change in viability of Acetobacter senegalensis cells during gluconic acid fermentation at high temperature, abstract no. PP13, p. 31Abstracts: how dead is dead III: life cycles, June 6-7, 2013. Technical University of Berlin, Germany (2013).

34. Giudici, P.: Acido gluconico: criterio di genuinità nell'aceto balsamico tradizionale, Ind. Bevande, 23, 123-125 (1993).

35. Falcone, P., Verzelloni, E., Tagliazucchi, D., and Giudici, P.: A rheological approach to the quantitative assessment of traditional balsamic vinegar quality, J. Food Eng., 86, 433-443 (2008).

36. De Ley, J.: On the fermentation of acetoin by Acetobacter, J. Gen. Microbiol., 21, 352-365 (1959).

37. Lu, S. F., Lee, F. L., and Chen, H. K.: A thermotolerant and high acetic acid producing bacterium Acetobacter sp. I14-2, J. Appl. Microbiol., 86, 55-62 (1999).

38. Azuma, Y., Hosoyama, A., Matsutani, M., Furuya, N., Horikawa, H., Harada, T., Hirakawa, H., Kuhara, S., Matsushita, K., Fujita, N., and Shirai, M.: Whole-genome analyses reveal genetic instability of Acetobacter pasteurianus, Nucleic Acids Res., 37, 5768-5783 (2009).

39. Gullo, M., Verzelloni, E., and Canonico, M.: Aerobic submerged fermentation by acetic acid bacteria for vinegar production: process and biotechnological aspects, Process Biochem., 49, 1571-1579 (2014).

40. Fukaya, M., Tagami, H., Tayama, K., Okumura, H., Kawamura, Y., and Beppu, T.: Spheroplast fusion of Acetobacter aceti and its application to the breeding of strains for vinegar production, Agric. Biol. Chem., 53, 2435-2440 (1989).

41. Nanda, K., Taniguchi, M., Ujike, S., Ishihara, N., Mori, H., Ono, H., and Murooka, Y.: Characterization of acetic acid bacteria in traditional acetic acid fermentation of rice vinegar (Komesu) and unpolished rice vinegar (Kurosu) produced in Japan, Appl. Environ. Microbiol., 67, 986-990 (2001). 